\title{
ULBP1 wt Allele
}

National Cancer Institute

\section{Source}

National Cancer Institute. ULBP1 wt Allele. NCI Thesaurus. Code C105581.

Human ULBP1 wild-type allele is located in the vicinity of $6 q 25$ and is approximately $10 \mathrm{~kb}$ in length. This allele, which encodes NKG2D ligand 1 protein, plays a role in the production of both cytokines and chemokines by natural killer cells. 